\title{
APPLICATION OF THE LEARNING COMMUNITIES APPROACH TO TEACHING ENGLISH FOR SPECIFIC PURPOSES
}

\author{
Nataliia Sukhachova, Valentina Voskoboinyk \\ Higher Educational Establishment of Ukoopspilka "Poltava University of Economics and Trade", Poltava, Ukraine \\ E-Mail: sukhachova2014@gmail.com, E-Mail: suc7us@ukr.net
}

\begin{abstract}
The paper focuses on the peculiarities of application of the Learning Communities to teaching English for Specific Purposes at the university. Combining two disciplines (a practical English language course and a business-oriented one) over a semester, around interdisciplinary themes requires intentional restructuring of students' time, credit, and learning experiences to build community, changing of the curriculum and fostering more explicit connections among students, between students and their teachers, teachers and administration, and among disciplines. The experience of using the Learning Communities approach has demonstrated the positive results for all involved. Studying real-life professional situations through case studies and problem-based tasks through collaboration in English, students benefit from both developing their English language competency and mastering the material on the disciplines related to their future professional field. Teachers experience a more coherent and enriched teaching environment. The university gets the opportunity to develop models for students' internships and cooperative education that are designed for the needs of local businesses and provide outreach to the community.
\end{abstract}

Key words: Learning Communities approach, English for Specific Purposes (ESP), collaborative teaching, business-related discipline

\section{INTRODUCTION}

The intensively developing globalized world requires from modern specialists in-depth understanding of national cultures and international trends. Higher school graduates need to have knowledge and skills that would enhance their competitiveness in a constantly changing business world. Nowadays business professionals must know not only what is going on but why. They must be able to interpret international events and assess their significance in wider national, regional, or worldwide contexts. The complexities of effective international communication place increasing demands on business professionals who must have the knowledge of economic theories and business practices, excellent language skills, a good command of English specifically used within business contexts, and the understanding of business people's expectations and psychology of personal and interpersonal interaction in cross-cultural settings. To achieve these goals, the course of ESP has been designed; it is centered on the language, skills, discourse, and genres appropriate to these activities (Dudley- 
Evans and St John 2003: 5). Nowadays, therefore ESP is becoming a need for highly qualified business specialists.

ESP usually refers to teaching the English language with reference to the particular professional vocabulary and skills people of a particular occupation or profession demand. In the context of dynamic development of international integration and exchange of information, ESP has become a communication tool that allows specialists sharing professional information effectively and efficiently.

ESP is the approach to teaching languages in which all decisions as to content and methods are based on the learner's reason for learning (Hutchinson and Waters 2006). At the level of university studies, ESP means teaching the English language to students of different specialties, e.g. Business English - to economics students, Technical English - to engineering students, English for Academic Purposes - to postgraduates conducting research, English for medical professionals - to medical students, English for Waiters - to hospitality students, etc. In this way, numerous links between basic disciplines and professions are established. Rather, the ways of teaching ESP reflects the changes that have been taking place in recent years within the framework of the European Higher Education Area, such as moves from contentand teacher-centered to student-centered and learning-centered educational trusts, disciplinary and multidisciplinary links, emphasis on rationally-based and values-based knowledge, and active collaborative teaching and learning environment. The most important change in the methodology of teaching languages, including ESP, has been to encourage students to be active participants in the learning process. With the spread of the student-centered approach and the increase of international contacts in various spheres, much attention has been paid to developing new ways of teaching ESP courses that can prepare students for professional communication.

Teaching ESP to university students of different business areas is achieved through the use of effective educational and pedagogical technologies aimed at establishing interpersonal relations, learning through active collaboration of a teacher and students, combination of rational and professional knowledge, the effective use of information technology in the educational process (Fry, Ketteridge, and Marshall 2009). One of the student-centered and practiced-based pedagogical technologies that tries to achieve these goals is the Learning Communities strategy. It has received much attention in recent years. This matching model encourages students to find solutions of real-life problems by learning in collaboration.

This article examines the peculiarities and results of the implementation of the Learning Communities strategy for teaching the languages of professional communication (the languages of Marketing, Economics and Management) at Poltava University of Economics and Trade (PUET). Taking into account our experience and the need of training highly qualified specialists in a business area, we would like to suggest that applying the Learning Communities strategy to teaching ESP is very promising.

\section{THE LEARNING COMMUNITIES STRATEGY: ORIGIN AND MAIN PRINCIPLES}

\subsection{The Origin of the Learning Communities Approach}

The origin of Learning Communities dates back to 1927 when Alexander Meiklejohn formed the two-year Experimental College at the University of Wisconsin where the faculty and students read and discussed classic Greek literature in the first year of study and compared 
it to contemporary American literature in the second year. This first attempt at the Learning Communities model provided the foundation for the Learning Communities we know today (Kelog 1999). At the end of the $20^{\text {th }}$ century, Jean Lave and Etienne Wenger switched to the idea that knowing and knowledgeability were better thought of as cultural practices that were applied by practitioners belonging to various communities (Lave and Wenger 1991). These communities were often termed communities of practice (Bos-Ciussi, Augier, and Rosner 2008). This led to learning and teaching in the classroom where students were encouraged to share their ways of doing Mathematics, History, Science, etc. with each other while participating "in the negotiation and institutionalization of ... meaning" (Roth and Bowen 1995). In effect, students were participating in Learning Communities. Learning Communities started gaining popularity at the U.S. colleges and universities during the late $80 \mathrm{~s}$ and throughout the 90 s.

The Learning Communities approach fundamentally restructures the curriculum, the time, and space of students. Many different curricular restructuring models are being used at present, but all of them intentionally link together courses or coursework to provide greater curricular coherence, more opportunities for active teaming, and interaction between students and faculty.

The Learning Communities strategy can take many forms. Nowadays five basic Learning Communities models are distinguished (Kelog 1999):

- linked course when students take two connected courses, usually one disciplinary course such as history or biology, and one skills course such as writing, speech, or information literacy;

- learning clusters when students take three or more connected courses, usually with a common interdisciplinary theme uniting them;

- freshman interest groups which are similar to learning clusters, but students share the same major;

- federated learning communities which are similar to a learning cluster, but with an additional seminar course taught by a master learner, a faculty member who enrolls in other courses and takes them alongside the students;

- coordinated studies when students study a single, giant course for an entire semester or academic year.

The first model of the Learning Communities strategy, which has been used successfully at our university, will be discussed below in more detail.

\subsection{The Essence of the Learning Communities Model}

"Learning" and "community" can be seen as both means and ends. "Community" means a strategy to strengthen learning and "learning" implies to work and to understand the value and the challenges of community more deeply. The basic theoretical premise is that the human individual needs to be understood and aided in the process of fulfilling values and goals. This is best done in community with others striving to attain the same goals (Omaggio 1986).

As it has been mentioned earlier, the experience of application of the Learning Communities approach involves linking or clustering classes during a given term, often around an interdisciplinary theme, that enrolls a common cohort of students. This represents an intentional restructuring of students' time, credit, and learning experiences to build community, changing of the curriculum and fostering more explicit connections among students, among students and their teachers, among teachers and administration, and among disciplines. 
This approach addresses the needs for:

- greater intellectual interaction between a student and a student, a student and faculty, faculty and faculty;

- curricular coherence through reinforcement and integration of ideas;

- understanding issues which cross subject matter boundaries;

- ways to facilitate the move to a richer, learning-centered environment;

- active and collaborative learning;

- exploring and understanding diverse perspectives;

- students' retention and progress toward degree;

- faculty development;

- low-cost method for doing the above.

Besides faculty members, other people are invited to participate in Learning Communities teaching, such as learning support specialists, academic advisors, residence life staff, librarians, computer technology specialists and students who can frequently serve as teachers, peer advisors and facilitators.

It should be noted that successful Learning Community implementation requires extensive cross-unit coordination of the following aspects: goals for the Learning Communities efforts, faculty requirements, faculty development support, Learning Communities models, planning calendar, scheduling of time and rooms, involvement of academic advisors, program delivery, assessment of students, and their self-evaluation.

In addition, the Learning Communities strategy helps reduce anxiety in the group to a minimum and promotes free expression of ideas and feelings. Learning Communities invite an array of pedagogical techniques including collaborative/cooperative learning, peer teaching, discuss groups and seminars, experiential learning, labs and field trips, problemcentered learning, lectures and demonstrations, writing and speaking across the curriculum, ongoing reflection, metacognitive activities, and self-evaluation.

\section{THE EXPERIENCE OF USING THE LEARNING COMMUNITIES MODEL AT THE UNIVERSITY}

\subsection{Application of the Learning Communities for Teaching the Languages of Professional Communication}

For more than a fifteen-year period, the Learning Communities approach has been utilized at PUET (Ukraine). The application of this technology at the university was pioneered with the help of professors who came to teach to our university from Holyoke Community College (HCC), the US institution where it received a solid academic foundation.

This strategy was a result of HCC partnership with PUET aimed at sustaining the close connection between the two institutions through the complementary objectives of curricular development, faculty and administrative exchange. Thanks to this longstanding partnership, the large Resource Center was established at PUET that enabled to implement the Learning Communities model.

While applying Learning Communities we combine two disciplines: a practical English language course (ESP) and a business-oriented course (Marketing, Economics, or Management) over a semester around interdisciplinary themes. As a result, new courses are created, for example, the English for Marketing, English for Economics, or English for Management. 
Integration of English with a range of business disciplines addressed the following specific needs:

- to foster the use of English throughout the university business curricula for understanding business in the global arena;

- to improve students' language skills, especially abilities in ESP;

- to adjust the university business curricula to the evolving Ukrainian business community by preparing highly-qualified business graduates;

- to design and implement educational strategies that integrate business content with the English language and enhance communication in a variety of areas;

- to develop models for internship and cooperative education in order to provide outreach to the local community;

- to use distance learning as a methodology for course delivery and increased educational access;

- to create new learning communities involving faculty from both institutions (PUET and HCC) and teachers of different courses linked.

The long-term impact of the strategy was to provide effective academic experience and relevant continuing education opportunities for business professionals and entrepreneurs in Ukraine.

In the framework of the Learning Communities approach, two courses are taught in English. First, a group of students attends a lecture and a practical class on a certain theme of a business-oriented course in English; then the same theme is discussed at the English practical class.

It is important that the latest English language textbooks, journals, and other business editions provided by the American funds for the university Resource Center are actively used by students. On the one hand, the English language becomes the tool for obtaining a significant amount of information on the disciplines related to the students' future professional activity while simultaneously developing their English language competencies (reading, speaking, writing, and listening skills). On the other hand, students have the opportunity to expand their knowledge of Management, Economics, and Marketing by working with the latest English-language sources and communicating with native speakers on a particular business theme.

The Learning Communities teaching involves a group of students engaged full-time in interdisciplinary active learning around themes. At the same time, the faculty development occurs through co-planning and team-teaching across disciplinary boundaries. Faculty teams of 2-3 co-plan the coordinated study around over-arching themes, or around related content/skills.

Generally, faculty members teach only in the coordinated study, but scheduling of class time can result in some difficulties of finding opportunities for lectures, discussions, workshops and presentations. Other problems that we have faced while applying the Learning Communities approach are the necessity for active involvement of students in the learning process, establishment of logical relationships between the courses, teaching of oral and written speech in the context of a certain discipline, strengthening better intellectual relationships between students and teachers, finding opportunities for teachers to review and update their pedagogical technologies. 


\subsection{Developing English Language Competencies with the Learning Communities Approach}

The Learning Communities strategy is communication in collaboration (Vicky Meaby, 2018) with the use of real-life situations and problem-based tasks; it makes students think globally while developing their analytical and critical thinking skills. At the same time, students get pleasure from solving important issues related to their future profession as the teaching techniques for solving professional problems in English are different. For example, for the analysis of the business material such forms of work as brainstorming, giving advice and support, recommendations, explanation, expressing the opposite opinion, presentations, writing essays are offered. To develop language skills, students are involved in thematic discussions, practice in various types of reading, work on vocabulary, learn grammar rules (conditional structures, modal verbs, tenses of verbs, etc.), listen to business texts and dialogues for comprehension, etc.

The most valuable thing about the strategy discussed is that students learn to think globally and act locally while communicating in English on the themes of their future professional field and using the latest information about the responsibilities that they will have to perform after graduation from the university.

Mastering a new created course, for example English for Management, can include the following types of work:

- oral interviews which mean teaching students the tactics and language during job interviews to achieve the expected results at the end;

- exercises for learning the terminological vocabulary. For this, students are required to have terminological glossaries, where they write the meaning of terms for each topic. Students can understand the meaning of new words and terms well by learning for clues in the business context, that is very effective. It is more important to use new words in a real situation;

- work with various lexical and grammatical structures;

- analysis of case studies that helps communicate in situations that are very close to real life;

- presentations on different topics followed by discussion. During presentations, students actively use a multimedia projector and other modern technical tools that are practiced by future business professionals at meetings and conferences;

- work with educational video and audio materials;

- doing written and computer tests, which ensure the assessment of students and a good feedback both in the process of studying a certain theme and before starting the next theme;

- finding and investigating additional resources from the Internet; it increases students' interest in both courses combined to be taught, opens opportunities for their research work and broadens their outlook;

- project management when the focus in and beyond classroom shifts from the learners' linguistic needs to the learners' actual needs to successfully and naturally acquire the target material through involvement of students in real business situations (Mamakou 2008);

- writing an essay on a proposed topic, etc.

We have mentioned the most practiced forms of work used by the university faculty to develop students' competencies in ESP and proved to be effective. However, teachers apply other teaching techniques depending on the theme being taught. 


\section{IS THE LEARNING COMMUNITIES STRATEGY EFFECTIVE?}

As the experience has shown, the Learning Communities strategy gives positive results for students, teachers, and the university. It deepens the practices that foster community by focusing on learning to learn in community, curricular connections and integration of ideas across disciplines, collaboration, reflective practice and synthesis by explicitly drawing the pieces into a whole.

\subsection{The Benefits of Learning Communities for Students}

As the Learning Communities approach has been developed to promote mutual understanding of business-related disciplines in the global business context in order to train highly competitive business graduates, students benefit considerably from it. The outcomes of the strategy for students are as follows:

1. The strategy ensures more effective learning languages of professional communication, as students use ESP to get knowledge and experience in their professional field.

2. Students' motivation and interest in the process of studying the language of the future profession increase due to their more intensive immersion in interrelated topics, themes or questions, as well as the use of the information obtained from English-language sources at their business-related classes.

3. The increased motivation of students results in the improved studies of the language and business-related courses.

4. Students have the opportunity to enrich their knowledge of Marketing, Economics, and Management using the latest information sources (textbooks, journals, newspapers and magazines); at the same time, it helps develop their reading, speaking and listening skills, abilities to write essays and make inspiring presentations.

5. Students develop their diagnostic, analytical, and critical thinking skills due to the analysis of case studies; these skills are of great importance for their career development and future success.

6. Students have access to a variety of online resources including textbooks, articles on specific topics, exercises, and other available sources on each theme.

7. The strategy develops the ability of students to work as a team; teamwork skills are very critical for their future professional activity.

During a conducted survey, the students have acknowledged that they improved their communication skills and learned how to work in collaboration; the tests have proved that students developed their receptive and productive skills in English.

\subsection{Faculty Outcomes of the Learning Communities Approach}

The teachers also benefit from Learning Communities as they experience a more coherent and enriched teaching environment by intentionally pairing courses into programs. Firstly, the faculty develops due to collaborative planning, delivering and reflecting on a coordinated program. Teachers have the opportunity to diversify their teaching methods, to review the content of courses and to find new ways of business language teaching by learning together, observing and evaluating each other's methods, that is, to learn together. This teaching approach ensures faculty development in terms of expended repertoire of teaching approaches, revised course content, and new scholarly interests resulting in refinement of teachers' qualifications. Secondly, teachers of the 
English language master the concepts of the business-related disciplines studied; teachers of Management, Economics, and Marketing receive access to the newest English-language resources on the course. Finally, the strategy described ensures faculty mentoring which is important for every educational establishment.

\subsection{Advantages of Applying the Learning Communities Model for the University}

Learning Communities give a good academic and scientific background for doing research at the university by establishing new connections between courses, curriculum development, and strengthening of teaching and learning. The Learning Communities approach also helps develop models for internships and cooperative education experiences for the university students that are designed to meet the needs of local businesses and provide outreach to the community. The strategy fosters implementation of distance learning as a methodology for course delivery and information access. International Business and Business Ethics courses were successfully taught in English to the students who had completed their courses of ESP by the HCC professors through distant learning technology.The long-term impact of implementing the Learning Communities approach is the enhanced capacity of PUET and HCC to provide effective academic experiences and relevant continuing education opportunities for business professionals and entrepreneurs in Ukraine.

\section{CONCLUSION}

The experience of application of the Learning Communities approach to teaching ESP (English for Management, English for Marketing, and English for Economics) has proven this model to be successful. Linking English and business-related disciplines thematically or by content for a cohort of students results in both developing students' English language competency and mastering the material on the disciplines related to the their future professional field. Studying real-life professional situations through case studies and problem-based tasks in collaboration makes students think globally and act locally while developing their analytical and critical thinking skills.

The Learning Communities model meets the need of business professionals to have excellent language skills, know the communicative functioning of English in business contexts, basic economic theories and business practices, and understand psychology of personal and interpersonal interaction in cross-cultural settings.

This strategy gives positive results for students, teachers, and the university: students and teachers experience a more coherent and enriched teaching and learning environment; the university gets the opportunity to develop models for students' internships and cooperative education that are designed for the needs of local businesses and provide outreach to the community. In the end, the Learning Communities approach provides business professionals with the knowledge and practical skills that would enhance their competitiveness in a constantly changing business world. 


\section{REFERENCES}

Bos-Ciussi, M., Augier, M., and Rosner, G. "Learning Communities Are Not Mushrooms - or - How to Cultivate Learning Communities in Higher Education", Communities of Practice: Creating Learning Environments for Educators, Vol. 2, Ch. 14 (2008) : 287-308.

Dudley-Evans, Tony and St John, Maggie Jo. Developments in ESP: A Multidisciplinary Approach. Cambridge : Cambridge University Press, 2003 : 302.

Fry, Heather, Ketteridge, Steve and Marshall, Stephanie. A Handbook for Teaching and Learning in Higher Education Enhancing Academic Practice. N. Y. : Routledge, 2009 : 525.

Hutchinson, T. and Waters, A. English for Specific Purposes: A Learning-centered Approach. Cambridge : Cambridge University Press, 2006. <https://assets.cambridge. org/97805213/18372/ excerpt/9780521318372_excerpt.pdf> (14 August 2019).

Kellog, K. "Learning Communities” ERIC Digest. Washington, D.C. : ERIC Clearinghouse on Higher Education, 1999. <https://www.ericdigests.org/2000-1/learning.html> (11 August 2019).

Lave, J. and Wenger, E. Situated Learning: Legitimate Peripheral Participation. Cambridge : Cambridge University Press, 1991. <https://pdfs.semanticscholar.org /11c7/75f8a059d6100ad7f5e499ab1300e4c1747f.pdf> (11 August 2019).

Mamakou, I. "Project-based Instruction for ESP in Higher Education." Handbook of Research on E-Learning Methodologies for Language Acquisition, 2008 : 456-479. <http://biblio.uabcs.mx/html/libros/pdf/12/28.pdf> (14 August 2019).

Meaby, Vicky. "Establishing Professional Learning Communities to Support the Promotion of Equality and Celebration of Diversity : Reflections from a North-East Community Learning Teacher", Teaching in Lifelong Learning, $8: 2$ (2018). <https:// www.teachinginlifelonglearning.org.uk/article /id/538/> (14 August 2019).

Omaggio, Alice O. Teaching Language in Context: Proficiency-oriented Instruction. Boston : Heinle and Heinle Publishers, Inc., 1986 : 480.

Roth, W.-M. and Bowen, G. M. "Knowing and Interacting: A Study of Culture, Practices, and Resources in a Grade 8 Open-Inquiry Science Classroom Guided by a Cognitive Apprenticeship Metaphor”, Cognition and Instruction, 13 (1995) : 73-128. 